Grimshaw, keeper of the Natural History Department, Royal Scottish Museum; Mr. J. Hedley, staff engineer, General Post Office; Dr. C. F. Lassalle, deputy surgeon-general and medical inspector of Health, Colony of Trinidad and Tobago; Mr. W. McAuslan, engineer surveyor-in-chief, Board of Trade.

\section{France and Great Britain in Africa}

M. Albert Sarraut, Ministre des Colonies of France, as chief guest at the African Society's dinner on May 23, was both apt and illuminating in the distinctions which he drew between French and British ideals and methods in the administration of native affairs in Africa. The whole of M. Sarraut's speech was inspired with a deep sense of the responsibility which lies upon the two nations-a responsibility "to protect and improve the destiny of the backward races, weighing more heavily than ever on our shoulders". He pointed out that "we are perhaps on the threshold of new times, in which the load that we bear will grow heavier". Even were there no stronger reason, it was the logical consequence of this view that M. Sarraut should enter on a comparison of the two systems of administration in their attitude towards this great problem. He displayed both knowledge and justice in his comparison. While he claimed for France a nearer approach to the life of the native, he admitted for Great Britain a greater regard for tradition. "You," he said, "listen especially to the prudent, but rather cold counsel of experience. We warm our actions in the flame of apostleship. You, in surn, wish the races to place themselves in a condition to make their own happiness; we wish ourselves to make their happiness urgently and with authority."

IT was evident that $M$. Sarraut had here in mind, more particularly, the methods of 'indirect rule' of Lord Lugard, of whom, indeed, he spoke most warmly. It is this which gives his speech its greatest significance for those whose interests lie in the application of scientific study to the problems of administration, For he went on to point out, what has indeed been apparent for some time in modifications which circumstances have brought about in French methods of administration, that France and Great Britain, with an identical object in view, are "bending towards a meeting point". With this as his justification he appealed for collaboration-an appeal addressed to all colonising nations. In connexion with M. Sarraud's remarks on Great Britain's regard for tradition and the convergence in method of the two systems of administration, it may not be inappropriate to direct attention to a communication which appears in a recent issue of Africa (vol. 6, pt. 2) referring to an expedition of M. Henri Labouret, of the École Coloniale, to French West Africa for the purpose of studying the social and economic organisation and the land system of the natives. Not only did this expedition have the official support of the Ministry of Education and the Minister for the Colonies, but also M. Labouret was accompanied by a graduate of the Ecole with a grant from the Rockefeller
Foundation to enable him to become acquainted with conditions in the field. This was in furtherance the policy of M. Labouret, himself, it will be remembered, a former Colonial Minister, of introducing trained ethnographers into the French colonial administrative service.

\section{Scientific Problems of the Pacific}

A NOTEWORTHy demonstration of the possibilities of long distance wire and radio telephony was given on June 5, when Lord Rutherford, speaking as the representative of science in Great Britain, delivered an address to the Fifth Pacific Science Congress assembled at Vancouver. Lord Rutherford, in the brief space of some eight minutes, touched on a number of problems closely identified with the work of the Congress. He reminded his audience that the investigation of their region was inaugurated by the British Government and the Royal Society more than a century and a half ago, when they sent Capt. Cook on his first voyage of discovery in the Pacific, accompanied by Sir Joseph Banks and other scientific observers. Lord Rutherford referred to the loss of the famous non-magnetic ship, the Carnegie, at Samoa, and to the recent investigations carried out in the Antarctic by the "Discovery" Committee and by the Great Barrier Reef Expedition, off the coast of Queensland. Speaking of notable advances in our knowledge of the transmission of radio waves, which have resulted in the discovery of at least two distinct reflecting layers in the upper atmosphere, he congratulated the Australian Radio Research Board on the valuable contributions its workers have made to our know. ledge of this question. He also stressed the importance of the problems of the depopulation of the islands of the Pacific, and of the preservation of the fauna and flora of the region. Lord Rutherford congratulated the Canadian organisers of the Congress on their courago and vision in arranging the meeting in spite of economic conditions, and said : "it is of good augury that representatives of all the countries bordering on the Pacific Ocean have met together in a spirit of friendliness and co-operation to discuss the multifarious scientific problems connected with the Pacific. Science is international, and I trust will ever remain so." After his address, Lord Rutherford had a conversation with Dr. H. M. Tory, president of the Congress, Prof. A. S. Eve, and others.

\section{Legal Size Limits and their Effect upon Fisheries}

Is California, more than twenty years ago, when the crab fishery was declining, an investigation carried out by F. W. Weymouth, of Stanford University, showed that the then minimum size limit of six inches was too low, since it permitted the destruction of male crabs before they had a chance to breed. On the evidence put before it, the Legislature decided to raise the limit at which the commercial crab might be taken, to seven inches. The result of so small a change has been rernarkable. A few years after the passing of the new regulation, when the first crop of crabs under its protection had reached the seven-inch size, the production of the 